\title{
Pandangan Tentang Kematian dan Kebangkitan Orang Mati dalam Perjanjian Lama
}

\author{
Sujud Swastoko \\ Sekolah Tinggi Teologi Gamaliel Surakarta \\ Korespondensi: sswastoko@gmail.com
}

\begin{abstract}
Abstrak
Artikel ini mencoba mencari jawaban atas pandangan terhadap kematian dan kebangkitan dalam Perjanjian Lama. Dalam Perjanjian Lama pembahasan masalah kematian dan kebangkitan orang mati serta penghakiman tidak begitu menonjol dibandingkan dengan dalam Perjanjian Baru, sehingga teks bacaan yang ada juga lebih sedikit. Oleh karena itulah persoalan tersebut menjadi menarik untuk diteliti lebih mendalam. Penelitian ini menggunakan metode penelitian kualitatif dengan pendekatan deskriptif, dengan mengambil sumber utama dari Alkitab Perjanjian Lama dan literatur yang mendukung. Berdasarkan hasil penelitian yang dilakukan, maka pada masa Perjanjian Lama orang memercayai kematian sebagai bentuk pemisahan tubuh dan rohnya. Saat mati, tubuh akan kembali menjadi debu, dan roh masuk ke dunia orang mati (syeol). Dalam Perjanjian Lama, orang percaya akan adanya kebangkitan tubuh (orang mati), yaitu bangkitnya tubuh secara fisik.
\end{abstract}

Kata kunci: Perjanjian Lama, kematian, kebangkitan, penghakiman.

\begin{abstract}
This article tries to find answers to views on death and resurrection in the Old Testament. In the Old Testament, the discussion of the death and resurrection of the dead and the judgment is less prominent than in the New Testament, so there are fewer reading texts. That is why the issue becomes interesting to be examined more deeply. This research uses a qualitative research method with a descriptive approach, by taking the main source from the Old Testament Bible and supporting literature. Based on the results of research conducted, then during the Old Testament, people believe in death as a form of separation of body and spirit. When dead, the body will return to dust, and the spirit enters the world of the dead (Sheol). In the Old Testament, people believe in the bodily resurrection (the dead), that is, the physical resurrection.
\end{abstract}

Keywords: Old Testament, death, resurrection, judgment.

\section{PENDAHULUAN}

Teks tentang kematian dan kebangkitan orang mati dalam Perjanjian Lama hanya sedikit dibahas dan tidak mencolok dibandingkan dengan teks dalam Perjanjian Baru. Orang-orang pada masa sebelum Kristus dibangkitkan lebih fokus pada tugas menjalankan kehidupan pelayanan mereka kepada Allah. Mereka hanya sedikit memberikan perhatian kepada kehidupan yang akan datang. Hal itu karena memang pada saat itu mereka belum menyaksikan kebangkitan Kristus dari kematian setelah mati disalibkan. Kadang-kadang orang-orang pada masa Perjanjian Lama menggunakan gagasan tentang kebangkitan untuk menyatakan harapan 
mengenai kelahiran kembali bangsa, seperti dituliskan dalam Yehezkiel $37 .{ }^{1}$

Selama periode antara dua Perjanjian, ketika bahaya tidak begitu menekan, gagasan tentang kebangkitan menjadi lebih menonjol dibandingkan masa sebelumnya. Namun, pada masa itu masih terjadi pertentangan tentang kebangkitan, karena orang Saduki yang memegang teguh Taurat Musa menolak adanya kebangkitan. Sedangkan orang Farisi tetap meyakini adanya kebangkitan orang mati. Namun pada umumnya mereka menganggap bahwa tubuh-tubuh yang sama ini akan dikembalikan hidup sebagaimana adanya sekarang. ${ }^{2}$

Tulisan ini mencoba menyajikan hasil penelitian melalui kajian literatur terkait pandangan terhadap kematian dan kebangkitan orang mati dalam Perjanjian Lama yang dipercayai orang-orang Yahudi pada masa sebelum Kristus lahir.

\section{METODE}

Penelitian ini menggunakan metode penelitian kualitatif. Penelitian kualitatif adalah penelitian yang menekankan pada quality atau hal yang terpenting dari sifat suatu barang/jasa. ${ }^{3}$ Metode kualitatif dilakukan dengan cara mengumpulkan data, dan analisisnya bersifat kualitatif. ${ }^{4}$ Data-data untuk penelitian ini diperoleh dari studi pustaka yang kemudian dianalisa untuk menjelaskan pandangan orang terhadap kematian dan kebangkitan orang mati pada masa Perjanjian Lama. Selain data dari buku-buku yang ada, penelitian juga dilakukan melalui penggalian Alkitab, baik Perjanjian Lama yang menjadi dasar dalam kehidupan masyarakat Yahudi pada masa itu, maupun dari Perjanjian

${ }^{1}$ J.D. Douglas (ed). Ensiklopedi Alkitab Masa Kini Jilid I (A-L), (Jakarta: Yayasan Komunikasi Bina Kasih, 2008), 146.

${ }^{2}$ Ibid.

${ }^{3}$ Djam'an Satori dan Aan Komariah, Metodologi Penelitian Kualitatif, (Bandung: Penerbit Alfabeta, 2009), 1 2.

${ }^{4}$ Sugiyono, Metode Penelitian Kuantitatif, Kualitatif, dan REDD, (Bandung: Penerbit Alfabeta, 2015), 8.
Baru yang yang mendukung kondisi pada masa Perjanjian Lama.

\section{PEMBAHASAN}

Orang Yahudi yang hidup pada masa Perjanjian Lama maupun antar Perjanjian (intertestamental) menggunakan Alkitab Perjanjian Lama sebagai pegangan hidupnya. Oleh karena itu, dalam memandang kematian dan kebangkitan orang mati, mereka akan mengacu pada kitab-kitab yang ada di dalam Perjanjian Lama. Namun demikian, untuk menemukan kebenaran tentang kematian dan kebangkitan orang mati ini, kita juga akan menggunakan acuan dari Alkitab Perjanjian Baru yang menggambarkan pandangan orangorang pada masa sebelum Kristus hadir di Israel, dan juga merupakan penggenapan dari Perjanjian Lama.

\section{Kematian Menurut Alkitab}

Pengertian kematian scara umum menurut Alkitab mencakup kematian jasmani (badani), kematian rohani, dan kematian kekal (maut). Kematian tubuh berbeda dengan kematian jiwa (nephesh dalam PL, dan psyche dalam PB). Dalam hal ini tubuh dianggap sebagai makhluk hidup, sedangkan nephesh (jiwa, nyawa), yang kadang juga muncul istilah roh (ruakh dalam PL, atau pneuma dalam PB) bagi manusia, yaitu elemen spiritual yang merupakan elemen dari kehidupan naturalnya. ${ }^{5}$ Penggunaan kata ruakh dan nephesh menurut James Montgomery dibedakan, yaitu ruakh menujukkan unsur yang dengannya manusia berhubungan dengan Allah, sedangkan nephesh sekadar pada prinsip hidup. Sesuai dengan pembedaan itu, "jiwa" sering digunakan dalam kaitan dengan binatang-binatang, tetapi "roh" tidak. ${ }^{6}$

Apabila tubuh terpisah dari roh, itulah yang disebut dengan kematian jasmani. Badan, yang

${ }^{5}$ Louis Berkhof, Teologi Sistematika buku 6: Doktrin Akhir Zaman (Surabaya: Penerbit Momentum, 2007), 17.

${ }^{6}$ James Montmogery Boice, Dasar-Dasar Iman Kristen (Surabaya: Penerbit Momentum, 2015), 163-164. 
diciptakan seperti badan kita, tampaknya harus mengalami kematian. Pada saat mati secara jasmaniah maka badan atau tubuh akan mengalami kerusakan dan terjadi proses pembusukan yang tidak terelakkan lagi. ${ }^{7}$ Secara fisik atau jasmaniah, mati berarti tidak berfungsinya lagi organ-organ tubuh yang vital, khususnya paru-paru, jantung dan otak, yang membuat manusia itu hidup. Dengan tidak berfungsinya organ-organ tersebut maka kehidupan dan aktivitas manusia terhenti dan berakhir. Kematian menyebabkan keberadaan dan kehidupan manusia di dunia ini menjadi hilang atau lenyap; berakhir dan tidak ada lagi. Tubuhnya yang sudah menjadi jazad atau mayat akan segera membusuk, binasa, dan habis. ${ }^{8}$

Alkitab Perjanjian Lama menyebutkan maut atau kematian sebagai akibat dosa manusia. Allah berkata kepada Adam, “... pada hari engkau memakannya, pastilah engkau mati." (Kej. 2:17). Pada saat Adam dan Hawa makan buah dari pohon pengetahuan yang baik dan yang jahat, mereka tidak langsung mati secara jasmani, namun roh mereka terputus dari Allah. Namun demikian, mereka akhirnya tetap mati, maka kematian badani/ jasmani terjadi sebagai akibat dari dosa. Secara natur, tubuh orang berdosa itu fana. Tetapi secara rohani, tubuh rohani itu baka. Maka, "upah dosa ialah maut" mengakibatkan terjadinya kematian jasmani dan kemudian ada hukuman maut yang lebih mengerikan dari sekadar kematian jasmani.

Kita bisa juga membaca dari Alkitab Perjanjian Lama, yaitu Kitab Pengkhotbah 12:7, "dan debu kembali menjadi tanah seperti semula dan roh kembali kepada Allah yang mengaruniakannya." Hal ini juga berkaitan dengan Kejadian 2:7 yang berbunyi, "ketika itu TUHAN Allah membentuk manusia dari debu tanah dan menghembuskan nafas hidup ke dalam hidungnya; demikianlah manusia itu menjadi makhluk yang hidup." Ketika nafas hidup (roh, ruakh) itu ada dalam tubuh manusia,

${ }^{7}$ J.D. Douglas (ed), Ensiklopedi Alkitab Masa Kini Jilid II: M-Z (Jakarta: Yayasan Komunikasi Bina Kasih, 2008), 35.

${ }^{8}$ Sutarno, Menyongsong Kehidupan setelah Kematian (Jakarta: Pustaka Sinar Harapan, 2012), 20. maka ia menjadi makhluk yang hidup. Pada saat nafas hidup itu tidak ada lagi, maka ia akan mati dan menjadi debu. "Sebab seperti tubuh tanpa roh adalah mati..." (Yak. 2:26).

Dengan demikian, kematian jasmani adalah berhentinya hidup secara jasmani melalui terpisahnya tubuh dan roh. Menurut Berkhof, kematian jasmani tidak pernah berarti kemusnahan, walaupun sebagian sekte menyebut kematian orang durhaka sebagai kemusnahan. Allah tidak pernah memusnahkan apapun yang Ia ciptakan. Kematian bukanlah akhir dari eksistensi, tetapi berubahnya hubunganhubungan natural dalam hidup. Hidup dan mati tidaklah saling berlawanan satu dengan yang lainnya sebagai eksistensi dan non-eksistensi. ${ }^{9}$

Ada beberapa hal terkait kematian yang dikutip dari tulisan Berkhof. ${ }^{10}$ Pertama, manusia diciptakan dalam gambar dan rupa Allah, dan dalam keadaan sempurna sebagai gambar Allah, maka tidaklah mungkin tampaknya jika manusia membawa benih kehancuran dan kematian. Dalam Kej.1:27 disebutkan, "Maka Allah menciptakan manusia itu menurut gambar-Nya, menurut gambar Allah diciptakan-Nya dia; lakilaki dan perempuan diciptakan-Nya mereka." Dan ciptaan Allah itu sungguh amat baik, "Maka Allah melihat segala yang dijadikan-Nya itu, sungguh amat baik.” (Kej. 1:31a).

Kedua, kematian fisik tidak disebutkan dalam Alkitab sebagai akibat natural dari kelangsungan keadaan asli manusia berkenaan dengan kegagalan manusia untuk meningkatkan diri sampai kepada taraf imortalitas oleh karena ketaatannya, tetapi sebagai hasil dari kematian rohani. Kejadian 2:17 menyebutkan, "tetapi pohon pengetahuan tentang yang baik dan yang jahat itu, janganlah kau makan buahnya, sebab pada hari engkau memakannya, pastilah engkau mati." Saat manusia itu melanggar perintah Tuhan, mereka mati rohani dan diusir dari Taman Eden, dan akhirnya Adam mati secara jasmani pada umur 930 tahun (Kej. 5:5).

Ketiga, pernyataan Alkitab jelas menunjuk kepada kematian sebagai sesuatu yang dibawa

\footnotetext{
${ }^{9}$ Louis Berkhof, Teologi Sistematika, 18.

${ }^{10}$ Ibid., 20.
} 
kepada dunia manusia oleh karena dosa dan sebagai hukuman atas dosa. Setelah manusia berdosa karena melanggar perintah Tuhan, maka manusia pada akhirnya akan kembali menjadi debu. "Dengan berpeluh engkau akan mencari makananmu, sampai engkau kembali lagi menjadi tanah, karena dari situlah engkau diambil; sebab engkau debu dan engkau akan kembali menjadi debu." (Kej. 3:19).

Keempat, kematian tidak disebutkan sebagai sesuatu yang natural dalam hidup manusia, sekadar kejatuhan dari sesuatu yang ideal, tetapi jelas sebagai sesuatu yang asing dan jahat bagi hidup manusia; merupakan sebuah ekspresi dari kemarahan Ilahi seperti yang dinyatakan pemazmur, "Sungguh, kami habis lenyap karena murka-Mu, dan karena kehangatan amarah-Mu kami terkejut. Engkau menaruh kesalahan kami di hadapan-Mu, dan dosa kami yang tersembunyi dalam cahaya wajah-Mu." (Mzm. 90: 7,8).

Kematian mengisi hati anak manusia dengan ketakutan dan kegentaran, sebab kematian dirasakan sebagai sesuatu yang tidak alamiah. Tentu saja semua ini tidak berarti tidak akan ada kematian dalam arti tertentu bagi ciptaan yang lebih rendah, terlepas dari dosa, tetapi bagaimana pun juga dosa membawa ikatan belenggu yang semula asing bagi setiap makhluk. ${ }^{11}$

Alkitab menyatakan tentang kematian sebagai hukuman, sebagai akibat dari pelanggaran yang telah dilakukannya (Kej. 2: 16,17). Adan Hawa makan dari pohon yang dilarang itu, dan mereka mati. Roh mereka, bagian mereka yang memiliki persekutuan dengan Allah, langsung mati. Kematian rohani mereka tampak jelas dari fakta bahwa mereka lari dari Allah ketika Allah datang kepada mereka di taman. Lebih lanjut, jiwa yang menjadi pusat intelektual, perasaan, dan identitas, mulai mati. ${ }^{12}$

\footnotetext{
${ }^{11}$ Ibid. 170.
}

\section{Dunia Orang Mati}

Kematian merupakan suatu hal yang tidak bisa dihindari oleh manusia. Setelah manusia mengalami kematian jasmani, tubuhnya akan dikuburkan dan kembali menjadi tanah, sedangkan roh atau nyawanya pergi ke tempat lain atau dunia yang lain. ${ }^{13}$ Itu artinya bahwa saat manusia masuk dunia orang mati, dia masih memiliki kehidupan yaitu roh atau nyawanya.

Tentang kehidupan setelah kematian ini, Henry Thiessen mengemukakan adanya dua pandangan, terkait dengan kondisi manusia apakah dalam keadaan sadar atau tidak. Menurutnya, dalam Perjanjian Lama tidak begitu jelas mengenai hal ini. Disebutkan bahwa berkumpul dengan kaum leluhur, turun mendapatkan anaknya, serta ungkapanungkapan lain semacam itu menyiratkan adanya kehidupan yang sadar, sekalipun hal itu tidak dinyatakan dengan gamblang. Pengkhotbah 9:5, 6, 10 nampaknya menolak bahwa kehidupan setelah kematian merupakan kehidupan secara sadar, karena ditegaskan di situ bahwa "tak ada pekerjaan, pertimbangan, pengetahuan, dan hikmat dalam dunia orang mati, kemana engkau akan pergi." Namun menurut pandangan Thiessen, ini dilihat dari sudut pandangan manusia duniawi. Hanya penyataan ilahi yang dapat menerangkan sifat yang sesungguhnya dari kehidupan setelah kematian. ${ }^{14}$

Dalam Pengkhotbah 14:9-11, 15-17 dengan jelas mengajarkan bahwa kehidupan setelah kematian adalah kehidupan yang sadar. Dan apa yang tersirat dalam Perjanjian Lama itu kemudian diajarkan dengan jelas dalam Perjanjian Baru. Yesus mengajarkan hal itu dalam Matius 22:31,32 dan dalam kisah orang kaya dan Lazarus (Luk. 16:19-31).

Selain kehidupan di dunia orang mati, maka di dalam Perjanjian Lama ditemui istilah syeol (atau Hades dalam istilah Perjanjian Baru), yaitu "tempat yang paling dalam", ke mana dan dimana roh semua orang mati pergi dan berada,

\footnotetext{
${ }^{13}$ Sutarno, Menyongsong Kehidupan, 32.

${ }^{14}$ Henry C.Thiessen, Teologi Sistematika (Malang: Penerbit Gandum Mas, 2015), 591.
} 
atau yang sering disebut juga sebagai "dunia orang mati”. Syeol merupakan tempat bagi orang fasik yang mati. Mereka akan pergi ke situ, seperti ditulis dalam Mazmur 9:18, "Orang-orang fasik akan kembali ke dunia orang mati, ya, segala bangsa yang melupakan Allah.” Juga di Mazmur 31:18, “... biarlah orang-orang fasik mendapat malu, dan turun ke dunia orang mati dan bungkam.” Dalam Yesaya 5:14 disebutkan, "Sebab itu dunia orang mati akan membuka kerongkongannya lapang-lapang, dan akan mengangakan mulutnya lebar-lebar dengan tiada terhingga, sehingga lenyap ke dalamnya segala kesemarakan dan keramaian Yerusalem...".

Syeol atau dunia orang mati ternyata bukan hanya untuk orang fasik saja, tetapi orang benar juga akan pergi ke situ. Seperti Ayub, seorang laki-laki yang saleh dan jujur, ia takut akan Allah dan menjauhi kejahatan (Ayb. 1:1). Ia ingin Allah menyembunyikan dirinya di dunia orang mati, "Ah, kiranya Engkau menyembunyikan aku di dalam dunia orang mati, melindungi aku, sampai murka-Mu surut; dan menetapkan waktu bagiku, kemudian mengingat aku pula!” (Ayb. 14:13). Ayub juga menyadari bahwa umurnya telah lalu, sehingga ia akan tenggelam ke dasar dunia orang mati, yaitu pada saat turun ke dalam debu (Ayb. 17:16). Daud dalam Mazmur 6:6 menuliskan, "Sebab di dalam maut tidaklah orang ingat kepada-Mu; siapakah yang akan bersyukur kepada-Mu di dalam dunia orang mati?" 15

Kematian merupakan jalan menuju kehidupan selanjutnya. Raja Hizkia memandang kematiannya sebagai memasuki "pintu gerbang dunia orang mati (syeol)". "Aku ini berkata: Dalam pertengahan umurku, aku harus pergi, ke pintu gerbang dunia orang mati aku dipanggil untuk selebihnya dari hidupku." (Yes.38:10). Pikiran pergi ke syeol nampaknya juga terdapat di dalam ungkapan yang sering dipakai, yaitu "dikumpulkan kepada kaum leluhurnya". Contoh lainnya adalah dalam Mazmur 16:10 disebutkan “... sebab Engkau tidak menyerahkan nyawaku dari dunia orang mati yang paling bawah." Kemudian Amsal 15:24, "Jalan

\footnotetext{
${ }^{15}$ Ibid., 590.
}

kehidupan orang berakal budi menuju ke atas, supaya ia menjauhi dunia orang mati di bawah." Di kitab Yesaya 14:15 dikatakan, "Sebaliknya, ke dalam dunia orang mati engkau diturunkan, ke tempat yang paling dalam di liang kubur.”

Dunia orang mati merupakan tempat yang sunyi, "Jika bukan TUHAN yang menolong aku, nyaris akan diam di tempat sunyi." (Mzm. 94:17), di mana keadaannya "kacau balau" dan "tidak ada cahaya sama sekali" (Ayub 10:21,22 "Sebelum aku pergi dan tidak kembali lagi, ke negeri yang gelap dan kelam pekat, ke negeri yang gelap gulita, tempat yang kelam pekat dan kacau balau, di mana cahaya terang serupa dengan kegelapan"), tidak ingat kepada Tuhan ataupun bersyukur kepada-Nya (Mzm. 6:6 Sebab di dalam maut tidaklah orang ingat kepada-Mu, siapakah yang akan bersyukur kepada-Mu di dalam dunia orang mati), tidak ada pekerjaan, pertimbangan, pengetahuan dan hikmat (Pkh. 9:10). Demikian pula tidak berkekuatan, terputus dari kuasa Tuhan, dalam kegelapan. (Mzm. 88:5-7). ${ }^{16}$

Dalam perkembangan kemudian, muncul pengertian bahwa dunia orang mati itu terbagi dua. Yaitu sebagai tempat keselamatan dan kebahagiaan bagi roh-roh orang benar, dan kesengsaraan serta penderitaan bagi roh-roh orang berdosa (Yeh. 32:17-32). Di kalangan para rabi Yahudi sejak abad ke-2 SM, Syeol diberi arti yang lebih sempit, yaitu hanya sebagai tempat penghukuman bagi roh-roh orang berdosa. ${ }^{17}$

Pandangan kematian dalam Perjanjian Lama tersebut berbeda dengan pandangan setelah kedatangan Tuhan Yesus Kristus (abad ke-1 M), karena dalam Perjanjian Baru ada anugerah keselamatan yang diberikan kepada manusia sehingga orang percaya masuk ke paradeisos atau firdaus, dimana mereka berada bersama Tuhan. Sedangkan orang-orang berdosa yaitu yang tidak percaya atau taat kepada Allah akan ke gehena (neraka) atau abussos (jurang maut). Di situlah tempat roh orang-orang berdosa menjalani hukuman mereka, yang diterjemahkan dengan "neraka" atau "api yang

\footnotetext{
${ }^{16}$ Sutarno, Menyongsong Kehidupan, 32-33.

${ }^{17}$ Ibid.
} 
menyala-nyala” sambil menunggu penghakiman terakhir saat Hari Tuhan. ${ }^{18}$

\section{Kebangkitan Orang Mati}

Perjanjian Lama mengajarkan bahwa kehidupan setelah kematian itu ada. ${ }^{19}$ Dalam Perjanjian Lama, juga disebutkan tentang kebangkitan orang mati. Hal ini dibuktikan dengan sedikitnya tiga orang dibangkitkan dari kematian: putra seorang janda (1 Raj. 17:21, 22), putra perempuan Sunem (2 Raj. 4:32-36), dan orang yang dibangkitkan ketika mayatnya kena kepada tulang-tulang Elisa (2 Raj. 13:21). Dengan kejadian tersebut, setidaknya Israel memiliki bukti tentang kemungkinan adanya kebangkitan tubuh. Selain itu juga pengharapan akan adanya kebangkitan tubuh yang dikemukakan Abraham agar Allah membangkitkan Ishak dari kematian (Kej.22:5; Ibrani 11:19). ${ }^{20}$

Kebangkitan orang mati dalam Perjanjian Lama juga kita temukan dalam tulisan pemazmur bahwa ia tidak akan ditinggalkan di Syeol (Mzm. 16:10). Juga pengharapan Yesaya akan suatu kebangkitan fisik (Yes. 26:19), janji Allah kepada Hosea (Hos. 13:14), janji Allah kepada Daniel (Dan. 12:1-3, 13). Dari uraian tersebut sudah jelas dan memadai untuk mengatakan bahwa doktrin ini telah diajarkan dan dipercayai sepanjang periode Perjanjian Lama. $^{21}$

Kebangkitan orang mati tidak sepenuhnya dipercayai oleh orang-orang Yahudi. Bagi orang Yahudi yang memegang teguh Perjanjian Lama, terutama Taurat Musa, memiliki dua pandangan yang berseberangan. Hal ini bisa kita baca dalam Matius 22:23, “...beberapa orang Saduki, yang berpendapat, bahwa tidak ada kebangkitan...", dan Kisah Para Rasul 23:8 yang mengatakan, "Sebab orang-orang Saduki mengatakan, bahwa tidak ada kebangkitan dan tidak ada malaikat atau roh, tetapi orang-orang Farisi mengakui

\footnotetext{
${ }^{18}$ Ibid., 34,35.

${ }^{19}$ Henry C. Thiessen, Teologi Sistematika, 590.

${ }^{20}$ Ibid., 592.

${ }^{21}$ Ibid., 593.
}

kedua-duanya." Dari dua ayat tersebut kita mengetahui bahwa orang-orang Farisi memercayai akan kebangkitan orang mati dan adanya malaikat serta roh, sedangkan orangorang Saduki tidak memercayainya.

Pandangan orang Saduki tentang kebangkitan orang mati juga menjadi pandangan Celsus, seorang filsuf Yunani yang menentang kekristenan pada abad pertama. Celsus menertawakan doktrin kebangkitan orang mati. Demikian pula penganut aliran Gnostik yang menganggap bahwa materi itu jahat, juga menolak kebangkitan orang mati. Pendapat itu ditentang oleh Origenes Adamantios (dari Aleksandria) yang tetap mempertahankan adanya kebangkitan orang mati. Namun, Origen tidak memercayai bahwa tubuh yang dikubur itulah yang akan dibangkitkan. Menurutnya, tubuh kebangkitan merupakan tubuh baru, yang dimurnikan, dan dirohanikan. ${ }^{22}$

Pendapat Origenes sendiri tentang tubuh yang akan dibangkitkan awalnya disetujui oleh Agustinus, namun belakangan Agustinus menerima pandangan mayoritas bahwa ada kesamaan dari tubuh yang sekarang dengan tubuh kebangkitan. Sedangkan Jerome (Hieronimus) menekankan kesamaan tubuh sekarang dengan tubuh kebangkitan sebagaimana diungkapkan tokoh mereka Gregorius, Chtysostom, dan Yohanes dari Damaskus.

Pandangan orang-orang Yahudi tentang kebangkitan orang mati sebelum Perjanjian Baru diduga juga mengacu pada pengertian tentang kebangkitan dari orang Persia. Pada masa itu Yahudi berada dalam penguasaan Imperium Persia dan dalam masa pembuangan. Budaya Persia berpengaruh terhadap orang Yahudi pada masa itu. Raja Mackintosh berkata, "Ada bukti kuat yang menunjang hipotesa bahwa pengertian mengenai kebangkitan masuk ke kalangan orang Ibrani dari Persia”. Salmond juga menyebutkan pandangan yang sama, tetapi ia menyebutkan bahwa memang dukungan terhadap pandangan tersebut kurang cukup. "Doktrin Perjanjian Lama tentang Allah cukup jelas untuk

\footnotetext{
${ }^{22}$ Louis Berkhof, Teologi Sistematika, 115.
} 
menjelaskan seluruh sejarah konsep Perjanjian Lama tentang hidup di masa yang akan datang." 23

De Bondt menyimpulkan bahwa tidak ada satu bangsa pun yang pernah berhubungan dengan Israel yang memiliki doktrin tentang kebangkitan orang mati yang bisa menjadi pola penjelasan dari apa yang kita jumpai di antara orang Israel sendiri. Kepercayaan kepada kebangkitan orang mati dalam Perjanjian Lama tidak memiliki akar dan dasar pada kepercayaan kafir, tetapi dapat dijumpai dalam wahyu Allah Israel. $^{24}$

Kepercayaan mengenai kebangkitan orang mati, sebenarnya sudah ada jauh sebelum zaman pembuangan. ${ }^{25}$ Para bapa leluhur Israel telah menanti-nantikan kebangkitan orang mati. Seperti dalam Ibrani 11:19 yang tertulis, "Karena ia (Abraham) berpikir, bahwa Allah berkuasa membangkitkan orang-orang sekalipun dari antara orang mati." Dalam Mazmur 49:16, pemazmur menulis, "Tetapi Allah akan membebaskan nyawaku dari cengkeraman dunia orang mati, sebab Ia akan menarik aku." Kemudian dalam Mazmur 73:24, 25 tertulis, "Dengan nasihat-Mu Engkau menuntun aku, dan kemudian Engkau mengangkat aku ke dalam kemuliaan. Siapa gerangan ada padaku di sorga selain Engkau? Selain Engkau tidak ada yang kuingini di bumi."

Penyataan Ayub juga menunjukkan kepercayaan mengenai kebangkitan. "Tetapi aku tahu: Penebusku hidup, dan akhirnya Ia akan bangkit di atas debu." (Ayb. 19:25). Lebih dari itu kebangkitan orang mati ini juga dengan jelas dituliskan dalam Yesaya 26:19, "Ya, TUHAN, orang-orang-Mu yang mati akan hidup pula, mayat-mayat mereka akan bangkit pula. Hai orang-orang yang sudah dikubur di dalam tanah bangkitlah dan bersorak-sorai! Sebab embun TUHAN ialah embun terang, dan bumi akan melahirkan arwah kembali."

Sesudah masa pembuangan, juga ada kepercayaan akan kebangkitan orang mati. Hal

\footnotetext{
${ }^{23}$ Ibid., 117.

${ }^{24}$ Ibid.

${ }^{25}$ Ibid., 118.
}

ini tersirat dalam kitab Daniel 12:2 yang menyebutkan bahwa, "orang-orang yang telah tidur di dalam debu tanah akan bangun, sebagian untuk mendapat hidup yang kekal, sebagian untuk mengalami kehinaan dan kengerian yang kekal." Sekalipun Daniel menggunakan kata tidur, namun pada umumnya para ahli berpendapat bahwa Daniel mengacu kepada kematian tubuh. Menurut N.T. Wright, seperti dikutip Mangapul Sagala ${ }^{26}$, pengertian tersebut telah dikenal secara luas dalam masa Daniel. Walaupun tubuh manusia sudah berubah menjadi debu, tetapi mereka akan dibangkitkan lagi untuk menghadapi penghakiman: Apakah mereka mendapat hidup yang kekal, atau mendapat kehinaan dan kengerian yang kekal.

Kepercayaan akan kebangkitan orang mati itu muncul, sebab kematian tidak akan meniadakan penghakiman Allah. Meski mati, hukuman atau pahala yang akan diberikan Allah sebagai hasil penghakiman-Nya, tidak batal. Untuk itu orang-orang mati akan dibangkitkan, guna menerima penghakiman Allah. Dengan adanya kebangkitan dari kematian itu maka kefanaan manusia pada hakekatnya ditiadakan, dan kebakaan atau kekekalan keberadaan manusia dipulihkan kembali. ${ }^{27}$

Pembahasan tentang kebangkitan orang mati dalam Perjanjian Lama memang tidak sebanyak di Perjanjian Baru. Dalam Perjanjian Baru, kebangkitan Tuhan Yesus Kristus menjadi klimaks peristiwa kebangkitan itu sendiri. ${ }^{28}$

Berkhof menuliskan tentang natur dari kebangkitan orang mati, ${ }^{29}$ yaitu: Pertama, kebangkitan adalah karya dari Allah Tritunggal. Kedua, kebangkitan ini adalah kebangkitan secara fisik atau jasmani. Ketiga, kebangkitan terjadi atas orang benar dan orang durhaka. Menurut Yosephus, orang Farisi menyangkal kebangkitan orang durhaka. Doktrin anihilisionisme dan doktrin imortalitas kondisional yang diajarkan oleh banyak teolog,

\footnotetext{
${ }^{26}$ Mangapul Sagala, Kristus Pasti Datang: Mengungkap Berbagai Spekulasi (Jakarta: Perkantas, 2009), 89.

${ }^{27}$ Sutarno, Menyongsong Kehidupan 41-42.

${ }^{28}$ Louis Berkhof, Teologi Sistematika, 118

${ }^{29}$ Ibid., 119.
} 
menyangkal kebangkitan orang jahat dan mengajarkan bahwa orang jahat akan musnah. Ini juga dipegang oleh Adventisme dan Millenial Dawnisme. Mereka percaya orang jahat akan lenyap begitu saja. Hal ini bisa dibaca dalam Daniel 12:2.

Menurut Alkitab ada kebangkitan tubuh, bukan suatu ciptaan baru yang seluruhnya berbeda, tetapi tubuh yang dalam arti mendasarnya sama dengan tubuh kita sekarang. Tuhan tidak akan menciptakan tubuh yang baru bagi semua orang, tetapi akan membangkitkan tubuh kita ini yang sudah dimakamkan dalam tanah. Kristus yang adalah buah sulung kebangkitan secara jelas menunjukkan kesamaan tubuh-Nya sebelum dan sesudah kebangkitan kepada para murid. ${ }^{30}$

\section{Waktu Kebangkitan}

Alkitab Perjanjian Lama menunjukkan bahwa akan ada kebangkitan baik orang benar maupun orang jahat. Seperti dalam Daniel 12:2, "Dan banyak dari antara orang-orang yang telah tidur di dalam debu tanah akan bangun, sebagian untuk mendapat hidup yang kekal, sebagian untuk mengalami kehinaan dan kengerian yang kekal."

Kitab Yehezkiel juga menuliskan dengan lebih jelas lagi tentang bangkitnya orang mati. Dalam Yehezkiel 37:7-10 tertulis:

"Lalu aku bernubuat seperti diperintahkan kepadaku; dan segera sesudah aku bernubuat, kedengaranlah suara, sungguh, suatu suara berderak-derak, dan tulang-tulang itu bertemu satu sama lain. Sedang aku mengamat-amatinya, lihat, urat-urat ada dan daging tumbuh padanya, kemudian kulit menutupinya, tetapi mereka belum bernafas. Maka firman-Nya kepadaku: "Bernubuatlah kepada nafas hidup itu, bernubuatlah, hai anak manusia, dan katakanlah kepada nafas hidup itu: Beginilah firman Tuhan ALLAH: Hai nafas hidup, datanglah dari keeempat penjuru angin, dan berembuslah ke dalam orang-orang yang terbunuh ini, supaya mereka hidup kembali." Lalu aku bernubuat

\footnotetext{
${ }^{30}$ Ibid., 120.
}

seperti diperintahkan-Nya kepadaku. Dan nafas hidup itu masuk di dalam mereka, sehingga mereka hidup kembali. Mereka menjejakkan kakinya, suatu tentara yang sangat besar."

Jika kita mengamati ayat-ayat tersebut, kita akan menemukan satu gambaran yang sedemikian jelas dan hidup tentang kebangkitan orang mati. Dapat dimengerti jika N.T. Wright berpendapat bahwa Yehezkiel 37:7-10 merupakan ayat yang paling terkenal dalam Perjanjian Lama, yang berbicara tentang kebangkitan. $^{31}$

\section{Penghakiman Orang Berdosa}

Penghakimana terhadap manusia telah dilakukan sejak manusia jatuh dalam dosa. Namun penghakiman setelah kematian akan dilakukan Tuhan dengan hukuman yang mengerikan. Pada saat manusia jatuh dalam dosa, Allah menghakimi mereka yang telah melanggar perintah Tuhan. ${ }^{32}$ Pertama kepada ular, kemudian perempuan, dan akhirnya lakilaki (Kej. 3:14-24). Terhadap ular, Tuhan Allah berfirman: "Karena engkau berbuat demikian, terkutuklah engkau di antara segala ternak dan di antara segala binatang hutan ...”. Kemudian kepada perempuan (Hawa), "Susah payahmu waktu mengandung akan Kubuat sangat banyak; dengan kesakitan engkau akan melahirkan anakmu ..." Dan kepada laki-laki (Adam), “..maka terkutuklah tanah karena engkau; dengan bersusah payah engkau akan mencari rezekimu dari tanah seumur hidupmu..."

Penghakiman atas Adam dan Hawa membawa dampak yang luar biasa bagi kehidupan manusia yang berlaku juga terhadap keturunan Adam dan Hawa. Hukuman atas penghakiman yang pertama adalah manusia diusir dari taman Eden, dengan usahanya sendiri manusia tidak akan memperoleh jalan untuk kembali ke dalam persekutuan dengan Allah. Setelah manusia berdosa, maka natur dosa itu

\footnotetext{
${ }^{31}$ Nico Syukur Dister, Teologi Sistematika 2: Ekonomi Keselamatan, (Yogyakarta: Kanisius, 2004),91.

${ }^{32}$ W.S. LaSor, D.A.Hubbard \& F.W. Bush. Pengantar Perjanjian Lama 1. (Jakarta: BPK Gunung Mulia, 2009), $122,123$.
} 
ada pada setiap manusia yang dilahirkan. Hukuman terhadap Kain yang telah membunuh Habel lebih berat lagi. Ia dihukum menjadi pelarian dan pengembara di dunia (Kej. 4:12).

Penghukuman Tuhan atas orang-orang yang melakukan kejahatan mencapai puncaknya saat manusia (kecuali Nuh dan keluarganya) dimusnahkan dari muka bumi ini dengan air bah. Tuhan memandang perbuatan manusia di dunia ini sudah sangat jahat dan tidak bisa dibiarkan lagi. Karena jahatnya, sampai Tuhan menyesal telah menjadikan manusia di bumi. "Ketika dilihat Tuhan, bahwa kejahatan manusia besar di bumi dan bahwa segala kecenderungan hatinya selalu membuahkan kejahatan sematamata, maka menyesallah Tuhan, bahwa Ia telah menjadikan manusia di bumi, dan hal itu memilukan hati-Nya." (Kej. 6:5,6). Pemusnahan manusia dari muka bumi dengan air bah diharapkan bisa mengubah manusia menjadi lebih baik, karena Nuh adalah orang yang taat dan takut akan Allah. Namun, ternyata perbuatan manusia masih tetap jahat di mata Tuhan sehingga penghukuman terus berlangsung.

Penghukuman Tuhan atas orang berdosa dalam zaman Perjanjian Lama adalah kesengsaraan yang ujungnya kematian (maut). Setelah keluarga Nuh diselamatkan, maka Allah mengadakan perjanjian dengan Yakub (Israel) yang akan menjadi umat-Nya, umat pilihan, dengan syarat mereka harus menyembah Tuhan, Allah Abraham, Ishak, dan Yakub. Tetapi bangsa pilihan yaitu Israel, juga memberontak terhadap Allah. Mereka menyembah allah lain dan membuat Allah murka. Allah telah mengirimkan para nabi, tetapi mereka berontak dari Allah dengan cara menyembah allah lain. Akibatnya selalu sama: kepedihan dan penderitaan, sakit hati dan kehancuran, kebinasaan dan maut. ${ }^{33}$

Dengan mengacu pada Perjanjian Lama, maka orang Israel percaya akan adanya penghakiman oleh Allah. Abraham mengakui Allah sebagai hakim segenap bumi (Kej. 18:25).

33 Josh McDowell dan Sean McDowell. The Unshakable Truth. (Malang: Gandum Mas, 2016),151.
Hana mengatakan bahwa "Tuhan mengadili bumi sampai ke ujung-ujungnya” (1 Sam. 2:10). Daud mengatakan bahwa Tuhan "datang untuk menghakimi bumi” (1 Taw. 16:33) dan mengatakan bahwa "Takhta-Nya didirikan-Nya untuk menjalankan penghakiman” (Mzm. 9:8). Dalam Yoel, Allah berfirman, "Baiklah bangsabangsa bergerak dan maju ke lembah Yosafat, sebab di sana Aku akan duduk untuk menghakimi segala bangsa dari segenap penjuru (Yl. 3:12). ${ }^{34}$

Penghakiman Allah yang dipahami orang Israel pada masa Perjanjian Lama adalah terjadi pada saat orang mati. Roh-roh orang benar akan berada di tempat keselamatan dan kebahagiaan, sedangkan bagi orang yang berdosa maka rohnya akan masuk ke tempat penghukuman, dimana terdapat kesengsaraan dan penderitaan. ${ }^{35}$

Dasar penghakiman adalah "berdasarkan apa yang ada tertulis dalam kitab-kitab itu" (Wahyu 20:12), yang berarti bagi orang Israel, dasarnya adalah Hukum Taurat dan kitab-kitab para nabi. ${ }^{36}$ Orang-orang fasik yang mati akan dihakimi berdasarkan bukti-bukti dari catatan perbuatan dan dari kitab kehidupan. Orang percaya akan diberi pahala sesuai dengan perbuatannya, tetapi orang yang tidak percaya (fasik) akan dihakimi sesuai dengan perbuatannya. ${ }^{37}$

Nasib orang-orang yang hidupnya tidak menaati perintah Tuhan dan mereka justru telah memberontak Allah akan mendapatkan hukuman yang mengerikan. Mereka akan merasakan kesakitan yang luar biasa karena hukuman yang harus mereka jalani. "Bangkai orang-orang yang telah memberontak kepada-Ku. Di situ ulat-ulatnya tidak akan mati, dan apinya tidak akan padam, maka semuanya akan menjadi kengerian bagi segala yang hidup." (Yes. 66:24).

\footnotetext{
${ }^{34}$ Henry C. Thiessen, Teologi Sistematika, 600.

${ }^{35}$ Sutarno, Menyongsong Kehidupan, 33.

${ }^{36}$ Henry C. Thiessen, Teologi Sistematika, 607

${ }^{37}$ Mounce dalam The Book of Revelation, seperti dikutip Henry C.Thiessen, 607.
} 


\section{KESIMPULAN}

Pandangan terhadap kematian dalam Perjanjian Lama merupakan terpisahnya tubuh dan roh (jiwa, nyawa) sebagai akibat dari pelanggaran manusia terhadap perintah Allah. Kematian jasmani menyebabkan tubuh kembali menjadi debu, namun roh berada di syeol, yaitu dunia orang mati. Mereka yang masuk dunia orang mati adalah orang fasik dan orang benar, sampai mereka menerima penghakiman dari Allah.

Orang-orang pada masa Perjanjian Lama memercayai adanya kebangkitan orang mati. Namun sebagian, yaitu orang-orang Saduki, tidak percaya adanya kebangkitan. Kebangkitan orang mati dipahami sebagai kebangkitan tubuh jasmani. Hal ini bisa kita temukan dalam Daniel 12:2, "Dan banyak dari antara orang-orang yang telah tidur di dalam debu tanah akan bangun, sebagian untuk mendapat hidup yang kekal, sebagian untuk mengalami kehinaan dan kengerian yang kekal.” Bagi orang Yahudi, kebangkitan orang mati adalah kebangkitan tubuh (jasmani).

Penghakiman Allah yang dipahami dalam Perjanjian Lama adalah orang akan dihakimi berdasarkan perbuatan mereka atas ketaatannya kepada Kitab Taurat. Orang-orang benar akan berada di tempat keselamatan dan kebahagiaan. Orang-orang fasik yang mati akan dihakimi berdasarkan bukti-bukti dari catatan perbuatan dan dari kitab kehidupan. Orang fasik akan menerima hukuman dalam kebinasaan.

\section{KEPUSTAKAAN}

Berkhof, Louis. Teologi Sistematika Volume 6: Doktrin Akhir Zaman. Surabaya: Penerbit Momentum, 2007.

Boice, James Montmogery. Dasar-Dasar Iman Kristen. Surabaya: Penerbit Momentum, 2015.
Dister, Nico Syukur. Teologi Sistematika 2: Ekonomi Keselamatan. Yogyakarta: Penerbit Kanisius, 2004.

Douglas, J.D. (Ed). Ensiklopedi Alkitab Masa Kini Jilid I:A-L. Jakarta: Yayasan Komunikasi Bina Kasih, 2008.

Douglas, J.D. (Ed). Ensiklopedia Alkitab Masa Kini Jilid II: M-Z. Jakarta: Yayasan Komunikasi Bina Kasih, 2008.

Kamus Besar Bahasa Indonesia. Jakarta: Balai Pustaka, 2005.

LaSor, W.S, D. A. Hubbard \& F. W. Bush. Pengantar Perjanjian Lama 1. Jakarta: BPK Gunung Mulia, 2009.

McDowell, Josh dan Sean McDowell. The Unshakable Truth. Malang: Gandum Mas, 2016.

Ord, David Robert \& Robert B.Coote. Apakah Alkitab Benar? Memahami Kebenaran Alkitab pada Masa Kini. Jakarta: BPK Gunung Mulia, 2016.

Ryrie, Charles C. Teologi Dasar - Buku 1. Yogyakarta: Penerbit Andi, 2001.

Sagala, Mangapul. Kristus Pasti Datang: Mengungkap Berbagai Spekulasi. Jakarta: Perkantas, 2009.

Satori, Djam'an dan Aan Komariah. Metodologi Penelitian Kualitatif, Bandung: Penerbit Alfabeta, 2009.

Sugiyono. Metode Penelitian Kuantitatif, Kualitatif, dan $R$ E $D$. Bandung: Penerbit Alfabeta, 2015.

Sutarno. Menyongsong Kehidupan Sesudah Kematian. Jakarta: Penerbit Sinar Harapan, 2012.

Tafsiran Alkitab Masa Kini 3: Matius - Wahyu. Jakarta: Yayasan Komunikasi Bina Kasih, 2010.

Thiessen, Henry C. Teologi Sistematika. Malang: Gandum Mas, 2015. 